\title{
ITALIAN FEMALE MINISTERS: A TEST FOR THE CELEBRITY POLITICS?
}

\author{
Authors: CAMPUS, Donatella and GIAMMARIA, Elena \\ Associate Professor - University of Bologna - Italy - donatella.campus@unibo.it \\ MA degree - University of Bologna - Italy - elegiamma88@ gmail.com
}

\begin{abstract}
The so-called celebrity politics is a well-known general and global phenomenon, common to most Western democracies. The celebrity politicians have become leading actors in tabloids, gossip magazines and entertainment TV programs. The paper aims at investigating the impact of those developments on women politicians and attempts at evaluating if they are advantaged or disadvantaged by the increasing celebritization of politics. By referring to the case of the Italian female ministers and through a content analysis of the most read Italian gossip magazine, the paper tests the hypotheses that female ministers receive more coverage than their male colleagues and that this coverage gives more space to trivial details, like appearance and attire. The paper argues that the celebrity politics may give women more visibility, but offers also some occasions for activating the most common and unfair gender stereotypes. Therefore, in the case
\end{abstract}

of male politicians, the coverage of gossip magazines can simply "humanize" their image by showing them in more private settings and allowing them to express their feelings and emotions. In the case of women, the same kind of coverage could reinforce an already biased treatment due to the fact that they usually receive more media coverage mentioning family life, dress and appearance than male politicians.

\section{Key words}

female politicians; gender stereotypes; celebrity politics; gossip magazines; Italian politics.

\section{Introduction}

The personalization of politics is a well-known general and global phenomenon, common to most Western democracies. Such a process has appeared as inextricably linked to the so-called mediatization of politics (Mazzoleni and Shultz 1999) since the mass media logic, especially the television logic, has pushed parties to put leaders and candidates at the center of political communication. The recent introduction of new media genres, with the surge of infotainment (Delli Carpini and Williams 1996), has encouraged a convergence between politics and political culture (Van Zoonen 2005). As a result of these two different developments- on the one hand, the personalization; on the other hand, the popularization of politics-, politicians have been increasingly covered by media as they were celebrities (Marshall 1997, Corner and Pels 2003). They have attained an "aura of celebrity" (Dahlgren 2009, 137) in the sense that they are covered in a way that is similar to what happens to the members of the star-system. In particular, the “celebrity politician” (Street 2003; Van Zoonen 2005; Wheeler 2013) has become a leading actor in tabloids, gossip magazines and entertainment TV programs.

As Langer $(2010,9)$ stressed in her analysis of the British case, "the personal is not only visible or public, but also politicized because it is used in the construction of a leader's persona and its assessment by the media”. Therefore, politicians' private lives 
have become increasingly central to political propaganda. In a comprehensive comparative account of several industrial advanced democracies James Stanyer (2013) revealed that the private lives of prominent politicians are a key feature of political communication: life stories, domestic and family life, tastes, hobbies, life-style choices are all scrutinized and illustrated by media.

What about the impact of those developments on women politicians? Are they advantaged or disadvantaged by the increasing celebritization of politics? First of all, it should be stressed that women are supposed to be more at ease with a personal style of communication, since they are commonly reputed to be more able to share feelings and express emotions. Because of this, in her analysis of television speeches, Kathleen Jamieson (1988) observed that women's narratives are "well suited for television" because this medium encourages a personal, selfdisclosing style. Therefore women's revelations about their personal memories, details about family life and inner self are likely to appear more authentic. Secondly, the popularization of politics promotes a process of intimization: not only politicians become "celebrities, but also "intimate strangers" (Stanyer 2007), that is to say people that the public does not know in person, but are very familiar to them. Also in this case women are more credible in sending a message of intimacy and closeness, since they are not conventionally seen as authoritative rulers, but rather project a softer image of power, sometimes even maternal (Schwartzenberg 1977). Being the coverage of gossip magazines or TV entertaining programmes focused mainly on relationships with relatives, family life, domestic space and disclosure of feelings, in principle women should be ideal protagonists of this sort of narratives.

A fundamental part of the intimization process concerns family relationships. While the families of male politicians have not been traditionally exposed to popular attention (with some notable exceptions like the President of US), women politicians have always been intensively scrutinized in their role of wives and mothers as if the experience of marriage and motherhood might contribute to their qualifications for a public office (Jamieson 1995;
Braden 1996). As a consequence, women should be more used to the disclosure of the details of their family life and domesticity than men. On the other hand, however, there are some possible biases. As Campus (2013, 96) underlines, "If being wife and mother is reassuring information if taken as the indicator of a caring, nurturing, trustworthy personality, the commitment to family raises speculation about the capability of reconciling private life with public duties". By contrast, if women politicians are single or childless, "they are pictured as deviant and perhaps cynical workaholics" (97). In other terms, the sphere of domesticity, which is traditionally regarded as the realm of women, may become a slippery ground for a woman who intends to pursue a political career (Van Zoonen 2006).

Another crucial aspect stressed by Van Zoonen (2006) is that celebrity for women is often linked to their appearance. The most famous women, those who are amply covered by gossip magazines, are mostly members of the star system, like actresses, top models, pop singers, all people for whom physical attractiveness is a key issue. Such habit of covering those women by giving a huge attention to their appearance, dressing and hairstyles, etc. can be even too easily extended to the coverage of women politicians. As observed by Falk $(2010,88)$ the fact that women politicians are physically described by media depends on cultural roots: women have been traditionally evaluated on the basis of their attractiveness since this resource was supposed to increase their ability of finding a husband. And "even if few in contemporary American society would agree with this, the persistence with which the press has tended to comment on women's appearance reveals the enduring legacies and unconscious ideologies of this value system". As a matter of fact, a large body of empirical evidence regarding different countries shows a clear gendered bias in the treatment of politicians' appearance (Sreberny-Mohammadi and Ross 1996; Freedman 1997; Carlin and Winfrey 2009). This phenomenon can be only more marked in popular media outlets, like in glossy and gossip magazines that tend to focus more on that sort of trivial aspects. 
In light of all this, in order to evaluate the impact of the increasing celebritization of politics on women politicians, the key issue becomes if such a development offers further occasions for activating the most common and unfair gender stereotypes. In other terms, in the case of male politicians, the coverage of gossip magazines can simply "humanize" their image by showing them in more private settings and allowing them to express their feelings and emotions. In the case of women, by contrast, the effect can be less positive. In fact, the same kind of coverage could reinforce an already biased treatment due to the fact that they commonly receive more media coverage mentioning family life, dress and appearance than male politicians.

\section{Objectives}

The main objective of this article is to ascertain if female politicians are likely to become protagonists of the process of celebritization of politics. If this is true, then, such recent developments of political communication could offer them more extended visibility and help them to become more popular and recognizable; however, the critical issue is if this kind coverage is not too easily dominated by a sort of "trivialisation effect", that is to say a disproportional attention given to details of private life and, above all, to their appearance and attire. As Stevens points out "trivialization is a form of symbolic sexism and another possible pitfall for female politicians" (2007, 138). Therefore, comments on women's body or dressing style cannot be considered as insignificant and not influential because "they reduce women to their traditional role of object, one who is seen rather than one that sees and acts" (Lakoff, 2003, 173).

Extended research on several case studies has shown that media tend to refer to the physical appearance of female candidates much more than they do with male candidates ${ }^{1}$. Since outlets like glossy and gossip magazines tend to focus more on trivial aspects, we will argue that, although the celebrity politics may help female politicians to generate identification within the public and to become recognizable, there is the risk that this style of communication activates and reinforces some common gender stereotypes. This effect could be further amplified if women are more covered by gossip media outlets than men.

With these research questions in mind, we intend to test two hypotheses $-\mathrm{H} 1$ : female politicians are more covered than their male colleagues in gossip magazines; H2: their coverage is more centered on

\footnotetext{
${ }^{1}$ For a review see Campus (2013, 74 and ff.).
}

trivial aspects, like dressing style, body appearance, etc. To do so, we will analyze Italian female ministers as a case study. Italy had a long-standing reputation of a low female political representation. In particular, for a long time, Italian governments have included just a few women, often confined in secondary roles (Saraceno 2013). Things have been changing in the space of the past few years: the number of women in Parliaments is now close to one third (with an increase of about 10 percent between 2008 and 2013) and the female proportion among ministers has reached the 50 percent in the current cabinet led by Matteo Renzi. As a consequence, women are more frequently in the political limelight than in the past; however, it has still to be evaluated if such a change has produced also an improvement in the quality of their coverage.

Furthermore, to increase the interest in the analysis of the Italian case, it should be observed that the Italian context is a paradigmatic example of the rise of the celebritization of politics. As shown by several studies on gossip magazines and TV programs (Mazzoni and Ciaglia 2014a; 2014b), Italian politics has definitively "gone popular". The first politician that has exploited these tools of communication has been Silvio Berlusconi, former Prime minister and leader of the main centre-rightist party. Berlusconi was a pioneer in the process of personalization of Italian politics when, in 1994, he founded a "personal party" (Calise 2000) and became Prime minister. He was very prone also to use to his advantage a storytelling based on his personality and his personal achievements. By voluntary disclosing many details of his private life as a propaganda strategy -i.e. during the electoral campaign of 2001 he sent a glossy leaflet on the 
history of his life to millions of Italians ${ }^{2}$ - Berlusconi influenced and deeply changed the context of Italian politics, which, until then, had been characterized by a greater respect of the "privacy zone" of politicians (Roncarolo 2004). As Mancini (2011, 33) suggested, he is a sort of "prototype", that embodies several global phenomena, like the personalization, the popularization, and the celebritization.

If Berlusconi's style of propaganda pushed the whole political context to emphasize the personal factor, the press attitude to feed the Italian public with reportages on the private lives of politicians has further increased following the sex scandals that affected Berlusconi in years between 2009 and 2011. Empirical research showed that the media covered extensively the sexual conduct of the Prime minister. Especially the quality press played a very active role, with some newspapers -like La Repubblica- attacking Berlusconi, and others -like Il Giornale- defending him (Cepernich 2010). It may be argued that such events left a mark on the practice of Italian journalism by further eroding the divide between public and private and opening the door to the acceleration of the celebritization of Italian politics.

With Berlusconi to act as a pioneer, it is not surprising that the celebritization process started in an asymmetric way, with he and many other politicians of the centre-right frequently using their private lives to attract visibility while politicians of the centre-left were almost absent from gossip magazine and TV shows (Mazzoni and Ciaglia 2014a; 2014b). For a considerable period, the Italian Left refused to adapt to the new rules of communication partly due to an ideological prejudice against the use of political marketing (Mazzoni and Ciaglia 2013a). Quite recently, however, much has changed with the rise of Matteo Renzi as the leader of the main centre-leftist party, PD, and, subsequently, as a Prime minister. After the long Berlusconi's predominance, Renzi has jumped to the top of the ranking of the most covered politicians in gossip magazines and entertaining TV programs (Ciaglia et al 2014). Younger than the average Italian political leader (he is in his late $30 \mathrm{~s}$ ), he has always been very attentive to the new communicative trends. He understands the need to reach audiences of all ages and social statuses and does not refrain from giving interviews to gossip magazines or appearing on entertainment TV shows. He has also modernized the Italian politics from the point of view of gender equality: his cabinet is that with the highest percentage of female ministers in the Italian history.

In light of all this, the rapid increase of celebritization of politics, the new attitude of the Left toward the potential of infotainment and soft news, and the developments concerning gender representation makes the Italian case very interesting. We will focus on the last four Italian government: Berlusconi (8 May 2008-16 November 2011); Monti (16 November 2011-27 April 2013); Letta (28 April 2013-21 February 2014), Renzi (22 February 2014now). As for the female representation in those cabinets, female ministers were 6 over 24 in Berlusconi's cabinet (Mara Carfagna, Equal Opportunity; Annamaria Bernini, European policies; Giorgia Meloni, Youth; Michela Brambilla, Turism; Stefania Prestigiacomo, Environment; Maria Stella Gelmini, Education); only 3 over 18 -but allocated in crucial roles- in Monti's government (AnnaMaria Cancellieri, Internal Affairs; Paola Severino, Justice; Elsa Fornero, Labour and Social Policies); 7 over 20 in Letta's (Cecile Kyenge, Integration; Josefa Idem, Equal Opportunity, Sport and Youth; Emma Bonino, Foreign Affairs; Annamaria Cancellieri, Justice; Nunzia de Girolamo, Agricolture; Maria Chiara Carrozza, Education; Beatrice Lorenzin, Healthcare); 8 over 16 in Renzi's government (Federica Mogherini, Foreign Affairs; Roberta Pinotti, Defense; Federica Guidi, Economic Development; Stefania Giannini, Education; Beatrice Lorenzin, Health care; Maria Elena Boschi, Institutional Reform; Marianna Madia, Public Administration; Maria Carmela Lanzetta, Regional Affairs). To stress the point, a long way has been walked in the space of a very few years: finally women are equally represented and no more confined in ministries dealing with "compassion issues", as they were for a long time. We are going to assess if such positive developments parallel an improvement in the way media cover women in power or if biases and prejudices still jeopardize female ambitions to the political leadership.

\footnotetext{
2 "Una storia italiana" (An Italian History), Mondadori.
} 


\section{Methodology}

The article is based on a content analysis of the issues published on the magazine "Chi" (Who) between the 7 th of July 2010 and the 30th of September $2014^{3}$. Chi has been selected because it is the most read Italian weekly gossip magazine with an average readership of $2.807 .000^{4}$. It is owned by Mondadori Group, the publishing house controlled by Berlusconi's family. As stressed by Ciaglia and Mazzoni (2014, 4) Chi can be regarded as "the primary arena for self-promotion for those politicians who make their private lives more public".

The goals of the content analysis were to assess: first, the quantity of coverage received by prime ministers, by ministers of their governments ${ }^{5}$, and by other relevant actors related to both groups (we included wives, husbands, partners, children, extra-marital lovers, close friends); second, what type of coverage they received. In the space of the period of time considered four subsequent governments were in office: Berlusconi (8 May 2008-16 November 2011); Monti (16 November 2011-27 April 2013); Letta (28 April 2013-21 February 2014), Renzi (22 Februarynow). Due to the characteristics of the archive we had access to, our analysis covers only partially Berlusconi's cabinet ${ }^{6}$. As for Renzi's government, which is still in office, we interrupted the analysis on the 30th of September 2014.

For each single article we identified the single person on which the coverage was centered on (with the only exception of articles dedicated to a group of ministers). Then, as for the quantity of coverage, we calculated the number of pages of each article and add up the total number of pages that the magazine

\footnotetext{
3 The whole set of findings on PM and government is illustrated in Giammaria (2014), an unpublished final dissertation discussed to get a two-year Master degree in Politics, Administration and Organization at the University of Bologna.

${ }^{4}$ Source of 2014 data: http://audipress.it/test/ accessed on November 1, 2014.

5 Among members of governments, we included also viceministers and undersecretaries.

${ }^{6}$ The authors are very grateful to Professor Marco Mazzoni who made kindly available the archive of the University of Perugia.
}

devoted to each political actor (the prime minister or the ministers) or to individuals related to the political actors. In such a way we obtained a rank of the most covered actors. This procedure allowed us to make a direct comparison of the quantity of coverage given to men and women ministers when they were in office.

As for the quality of coverage, our main distinction was between contents related to the institutional and the political sphere (including positions on issues and policies, institutional activities, alliances, relationship with colleagues, etc.) and contents related to the private sphere. Following a suggestion bu Marco Mazzoni and Antonio Ciaglia, we designed four categories: "institutional" that includes all activities related to their political role, from positions on issues to alliances; "individual" (including life-style choice, tastes, ways of behaving, etc.); "relational" (including relationship with family, partners, and extra-marital lovers); "spatial" (including domestic spaces, off-duty locations where the politician should enjoy some privacy like holidays, etc.). The last three categories have been developed following Stanyer's analysis $(2013,15)$. Then we proceeded to classify the content of each article in just one of the four categories. When the article involved aspects referring to multiple categories, it was classified in just in one of them according to a criterion of salience and main relevance. 


\section{Main findings and discussion}

Our first finding concerns the overall quantity of coverage given to each government. As mentioned before, not only the analysis took into consideration political actors, but also people related to them through an intimate relationship (like partners, relatives and lovers). Table 1 shows the total number of pages referred to each government and the index of coverage, which is obtained by dividing the number of days in which the government was in office by the number of pages that the magazine has dedicated to the PM or to a minister of his cabinet, or to some other relevant actors. The lower is the index the more covered is the government. Accordingly, the government that attracted more coverage appears to be that led by Silvio Berlusconi, followed by Matteo Renzi's, Mario Monti's,'s, and Enrico Letta's ones.

Table 1: Total coverage of PMs, ministers and all other relevant actors.

\begin{tabular}{|c|c|c|c|c|}
\hline & Lengh of time & $\begin{array}{c}\text { Number } \\
\text { of days }\end{array}$ & $\begin{array}{c}\text { Coverage } \\
\text { index }\end{array}$ & $\begin{array}{c}\text { Total number } \\
\text { of pages }\end{array}$ \\
\hline Berlusconi & 7 Jul. 2010-16 Nov 2011 & 497 & 1,29 & 385 \\
\hline Monti & 16 Nov 2011-27 Apr 2013 & 533 & 8,59 & 62 \\
\hline Letta & 28 Apr 2013-21 Feb 2014 & 297 & 14,14 & 21 \\
\hline Renzi & 22 Fb 2014-30 Sept 2014 & 220 & 5,64 & 39 \\
\hline Total amounts & 7 Jul 2010-30 Scp 2014 & 1547 & 3,05 & 507 \\
\hline
\end{tabular}

Figure 1 shows the coverage given to the PM, that given to ministers and that given to the circle of relatives of the PM and of his ministers. Figure 2 focus only to the coverage given to ministers by gender.

Figure 1: Coverage by categories (PM, Ministers, Other relevant actors).

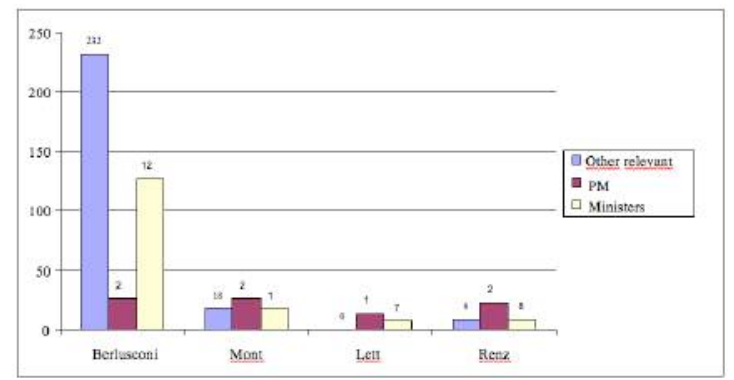

Figure 2: Ministers' Coverage by Gender

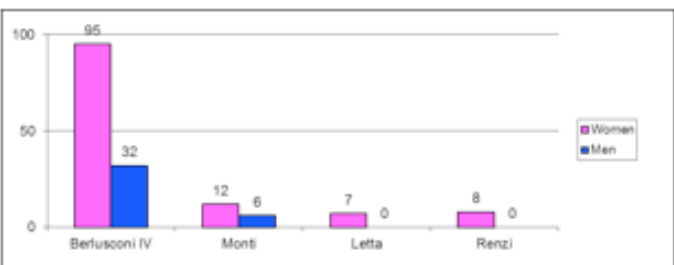

The most evident finding is that female ministers' coverage prevails over that of their male colleagues. In the case of the last two cabinets, indeed, male ministers are totally neglected: all the coverage concerns the PM and some female ministers. Our data confirm the findings of previous studies on the celebritization of politics in Berlusconi's era. Mazzoni and Ciaglia (2014a) highlighted a predominance of women among the most covered political actors in gossip magazines. As a matter of fact, with the exception of Berlusconi himself, most of the other covered actors were female politicians of the centre-right or, even more frequently, Berlusconi's female relatives, like his exwife or his daughter. This disproportion in favor of women could be interpreted as an effect of the typical Berlusconi's storytelling: on the one hand, he wished to interpret the role of the family man - whose private life was a sort of fairy tale; on the other hand, he did not refrain from presenting himself as an Italian latinlover who appreciates and courts women (Ventura 2012). As a consequence, his public image was always associated to a circle of women, partly family relatives, partly political collaborators.

Given the characteristics of Silvio Berlusconi's peculiar image and his huge impact on Italian political culture one may wonder if his style has not deeply influenced the forms of celebrity politics when he was in power. In answer to the question if the prominent role of women politicians in Italian gossip magazines was consequential to Berlusconi's exceptionalism or reflected a more general trend, however, our findings seem to support the view that female ministers are generally more covered than their male colleagues. It is a fact that such a disparity continues also after the end of his government and applies also to the other three 
cabinets. Even when the overall coverage of a government is limited, female ministers seem to attain more visibility.

Overall such findings validate our first hypothesis $\mathrm{H} 1$ : with the obvious exclusion of leaders, who have the lion's share, female politicians are more covered than men in gossip magazines. This supports also the belief that the feminine nature is especially congenial to this popular style of communication and women politicians are likely to become protagonists of the process of celebritization.

As for the quality of coverage given to female ministers, we classified the articles in four categories: "individual" that includes coverage of habits, life-style choices, tastes; "relational" that includes coverage of the subject with his/her family or lovers; "spatial" that includes reports on off-duty activities, like holidays; "institutional" that includes all activities related to their political role, from positions on issues to alliances. Tables 2a; b, c, d show the classification of articles referred of each female ministers in the four government under consideration.

\section{Table 2a: Quality of Coverage of Female Mi-} nisters- Berlusconi's government.

\begin{tabular}{|c|c|c|c|c|c|}
\hline & Individual & Relational & Spatial & Istitutional & $\begin{array}{l}\text { Total Number } \\
\text { of pages }\end{array}$ \\
\hline Ministers & & & & & \\
\hline $\begin{array}{c}\text { Anna Maria } \\
\text { Bernini }\end{array}$ & & 3 & 4 & & 7 \\
\hline $\begin{array}{c}\text { Daniela } \\
\text { Santanchè }\end{array}$ & & 8 & & & 8 \\
\hline Giorgia Meloni & & 4 & 3 & & 7 \\
\hline Laura Ravetto & 15 & 6 & & 21 \\
\hline Mara Carfagna & 16 & & 7 & 23 \\
\hline $\begin{array}{c}\text { Maria Stella } \\
\text { Gelmini }\end{array}$ & & 4 & 2 & 11 & 17 \\
\hline $\begin{array}{c}\text { Michela } \\
\text { Vittoria } \\
\text { Brambilla }\end{array}$ & & & & 5 & 5 \\
\hline $\begin{array}{c}\text { All female } \\
\text { ministers }\end{array}$ & & 50 & 15 & 30 & 95 \\
\hline $\begin{array}{c}\text { Stefania } \\
\text { Prestigiacomo }\end{array}$ & 0 & & & 3 \\
\hline & & & & \\
\hline
\end{tabular}

Table 2b: Quality of Coverage of Female Ministers- Monti's government.

\begin{tabular}{|l|c|c|c|c|c|}
\hline & Individual & Relational & Spatial & Istitutional & $\begin{array}{c}\text { Total } \\
\text { Number } \\
\text { of pages }\end{array}$ \\
\hline Ministers & & & & & \\
\hline $\begin{array}{l}\text { Anna Maria } \\
\text { Cancellieri }\end{array}$ & & & 3 & & 3 \\
\hline $\begin{array}{l}\text { All female } \\
\text { ministers }\end{array}$ & & & & 4 & 4 \\
\hline Paola Severino & & & 2 & 3 & 5 \\
\hline & 0 & 0 & 5 & 7 & 12 \\
\hline
\end{tabular}

Table 2c: Quality of Coverage of Female Ministers- Letta's government.

\begin{tabular}{|l|c|c|c|c|c|}
\hline Ministers & Individual & Relational & Spatial & Istitutional & $\begin{array}{c}\text { Total } \\
\text { Number of } \\
\text { pages }\end{array}$ \\
\hline Cécile Kyenge & & & & 3 & 3 \\
\hline $\begin{array}{l}\text { Nunzia De } \\
\text { Girolamo }\end{array}$ & & & & 4 & 4 \\
\hline & 0 & 0 & 0 & 7 & 7 \\
\hline
\end{tabular}

Table 2d: Quality of Coverage of Female Ministers- Renzi's government.

\begin{tabular}{|l|c|c|c|c|c|}
\hline Ministers & Individual & Relational & Spatial & Istitutional & $\begin{array}{c}\text { Total } \\
\text { Number } \\
\text { of pages }\end{array}$ \\
\hline $\begin{array}{l}\text { Maria Elena } \\
\text { Boschi }\end{array}$ & & & 4 & & 4 \\
\hline $\begin{array}{l}\text { All female } \\
\text { ministers }\end{array}$ & 1 & & & & 1 \\
\hline $\begin{array}{l}\text { Stefania } \\
\text { Giannini }\end{array}$ & & & 3 & & 3 \\
\hline
\end{tabular}

The most interesting and evident feature is the scarcity of political contents. The only notable exceptions are the two articles dedicated to Letta's female ministers, both classified in the "institutional" category. The dimension of family life and personal relationship dominates especially the coverage given to Berlusconi's female ministers. This is quite in line with previous expectations. As observed before, the roles that women perform in their private lives -wife, mother, grandmother- have always been associated to female politicians and are primary objects of media attention. Information about husbands, children, and grandchildren are commonly available in media coverage (Jamieson 1995, Falk 2010): therefore, no surprise if they dominate also the narratives of gossip magazines.

To analyze in more details some paradigmatic cases, we may consider, for instance, one of the favorites of Chi, Mara Carfagna, minister of Equal Opportunities. She is the protagonist of five articles, which range from the reportage of her marriage to the pictures of her on holidays wearing a bikini. The most regularly covered political actress during Berlusconi's term is Maria Stella Gelmini, minister of Education. She promoted a controversial reform and, therefore, was at the centre of the political debate, but little of this appeared on the pages of Chi where Gelmini performs her role of young 
mother of baby Emma in most of the articles dedicated to her.

It should be said that also the coverage given to male ministers is characterized by the predominance of the "relational" category as well. Taken all together, they received a coverage of a total number of 24 pages vs. 10 in the institutional category. Moreover, it should be added that, while in the case of female ministers, there were no article concerning relatives, 14 pages are directly dedicated to the wives and children of male ministers. By contrast, what really differs from the coverage of their female colleagues is the minor emphasis given to the "spatial" category, where men received only 4 pages of coverage. This is a notable aspect since in the "spatial" category are collected some striking examples of "trivialization effect".

From this point of view, the coverage of ministers in Renzi's government is especially suggestive. Two articles, in particular, may be regarded as a true triumph of the "trivialization effect". The one shows several pictures of the Minister of Institutional Reform, Maria Elena Boschi, in a bikini on the seaside. The headline is evocative: "Maria Elena Boschi. She is the most beautiful of the summer". Both articles focuses on a picture of Stefania Giannini, Minister of Education, while she was taking a tan in topless. Both the articles had a remarkable impact on the media system as a whole: immediately most newspapers and also news agencies reported the news while the pictures of the two ministers widely circulated and were discussed on social networks.

Another article concerns the whole group of Renzi's female ministers. While analogous articles on the female ministers of Berlusconi's and Monti's cabinets were the occasion for discussing themes like equal opportunities and quota $^{7}$, that on Renzi's ministers is a frivolous discussion about how they were dressed for the formal cerimony of the oath of office ${ }^{8}$. In summary, gossip magazines continue to prefer female to male political actors also in the post-Berlusconi era. What is peculiar is that today women's coverage seems to be

\footnotetext{
7 "Valanga rosa" (A pink avalanche), Chi, 16 February

2001; “Aria nuova” (A new air), 30 November 2011.

8 "Vestiti, giuriamo" (Dress up, let us take the oath), Chi, 5 March 2013.
}

even more affected by the phenomenon of the objectification of female bodies. The most striking example is not included in our quantitative analysis, but it worth being mentioned. On the issue of 12 th of November 2014 "Chi" featured some pictures of Marianna Madia, minister of Public Administration, eating an ice-cream. Pictures were accompanied by the headline "Ci sa fare col gelato" (She has a talent with the icecream), so insinuating a sexist and vulgar association with sexual acts. This article has filled the public opinion with indignation and Chi's editor has been forced to make public apologies ${ }^{9}$.

Leaving aside this example, Chi's publishing line is not really deviant from a common trend. In particular, if the premier Matteo Renzi is the chief communicator and the indisputable leading actor of the Italian pop politics, it is worth noting that Maria Elena Boschi has become the female "celebrity" of his government. A 33 years-old woman, in charge of promoting many important institutional reforms, Boschi is often the protagonist of female or gossip magazines: from a cover and a long interview on Vanity Fair ${ }^{10}$ to the reportages appeared on another popular gossip magazine, Oggi (which has published picture of her in bikini as well ${ }^{11}$ ). Very recently, in the space of just three weeks, Chi has published an interview to her ex-fiance and some pictures of her playing with her dog so confirming the impression that Boschi is really becoming a celebrity politician $^{12}$.

To sum up, our data seems to validate also our second hypothesis, $\mathrm{H} 2$ : there is a certain degree of

\footnotetext{
${ }^{9}$ http://www.ansa.it/sito/notizie/politica/2014/11/ 08/caso-madia-signorini-chiede-scusa_62b64dd2-b06f4377-8b03-783daa42fc3f.html

10 "Il summit del cuore" (Il summit of the heart) Vanity Fair, 30 April 2014.

11 "Signorina grandi riforme", (Miss Great Reforms) Oggi, 16 July 2014; "Maria Elena Boschi si lascia scappare il topless. Ma il lato B è da rivedere.." (Maria Elena Boschi risks to go topless. But she should fix her "Bside”) Oggi, $21 \quad$ August 2014 (http: / /www.oggi.it/gossip/hot/2014/08/21/amaria-elena-boschi-scappa-il-topless-ma-il-lato-b-e-darivedere; accessed on Nov, 8 2014).

12 "Tommaso Romoli: ho amato la Boschi” (I loved Boschi) Chi, 29 October 2014. "Maria Elena Boschi: il mio amico più fedele" (My best friend), Chi, 12 November 2014.
} 
trivialization in how women politicians are covered by gossip magazine. This does not mean that their male counterparts are covered only in an institutional way: on the contrary, the private life of both sexes is fully explored. However, especially in the case of Renzi's government, the coverage of women shows a disproportional attention to their body appearances, clothing and attire.

Another interesting aspect that emerges from the comparison between the four governments is the fact that they enjoyed dissimilar quantity and quality of coverage. Letta's cabinet, for instance, has been almost neglected by Chi: the coverage of the leader himself and of his ministers is minimum. The $50 \%$ of the overall coverage given to them can be classified in the category "institutional", including the only two articles dedicated to female ministers. The most obvious explanation is that Letta is a centre-leftist premier and Chi is owned by Berlusconi's family, so not very inclined to publicize Berlusconi's adversaries. This is, however, disconfirmed by the fact that Renzi's government, which has the same political alignment as Letta's, is the second most covered of all and Matteo Renzi results to be the most covered leader ${ }^{13}$. So Chi does not appear to adopt a strategy of obscuring Berlusconi's rivals, at least not that of obscuring those leaders that can be regarded as "lukewarm opponents", that is to say those that Berlusconi does not perceive as true enemies (Ciaglia and Mazzoni 2014, 13).

Beyond specific cases, one may argue that, in a framework of a general increase of the publicity surrounding leaders' personal lives, there are personal differences (Stanyer 2012, 37 and ff.). Just for some leaders, who are gifted with the suitable traits, personal life becomes a media spectacle. As Langer (2010, 67) observed by making a comparison between British prime ministers, "the extension of the politicization of the private persona depends on how skillful leaders are in using personal lives for strategic publicity". Following this line, we may advance the hypothesis, but we are not able to test it here, that the visibility and the communication style of a leader influence the

\footnotetext{
13 The indexes of coverage of each single leader are: 9,57 Renzi; 19,12 Berlusconi; 20,05 Monti; 21,21 Letta.
}

quantity and the tone of attention surrounding his collaborators as well. It may well be that the flamboyant style of Matteo Renzi, young and smart new leader of the Italian Left, attracts much attention on him, but also has an impact on the kind of coverage given to his female ministers. In this regard, one may establish a suggestive comparison with what happened to Alain Juppé government in France (1995-1997) when the press named the female ministers "les jupettes" or to Tony Blair when female Labour MPs were labeled "Blair's babes" (Stevens 1997, 74). In both cases, the symbolism evoked a relationship and dependency with the leader (Campus 2013, 74). A similar mechanism could have worked for Matteo Renzi, but not for Enrico Letta. This is due to their different approach to leadership. Enrico Letta has never shown a propensity for "going personal", but, in contrast to Renzi, he is has always adopted a sober and understated style. Therefore, we may argue that Italian politics is following the trajectory of the celebritization of politics, but not all leaders and politicians fit the model adequately. Only those who have some specific requisites are able to embody such a phenomenon. 


\section{Conclusions}

The analysis of the case of Italian female ministers allowed us to highlight several aspects of celebrity politics in relation to the gender issue. First of all, the belief that women are interesting subjects for gossip magazines has been confirmed. Although women politicians often complain that they have minor access to media than their male colleagues, this is not true for this specific kind of outlets. A possible line of explanation lies in the fact that gossip magazine and entertaining TV programs tend to cover regularly and extensively typical female celebrities of the starsystem, like actresses, singers, top-models and members of royal families. In other terms, women do not play a secondary role in this kind of media outlets. Therefore, it is not surprising that gossip magazines are inclined to cover women politicians not less than men and, sometimes, even more.

What should be stressed here is that the extension of coverage in gossip magazines is not necessarily matched by the overall media coverage. According to data released by The Global Media Monitoring Project (2010), in Italy the percentage of women politicians who are news subjects is $11 \%$ vs the $89 \%$ of men. Presumably these figures are destined to improve over time as a consequence of the recent increase of female representation, but it is unlikely that the situation will be totally reversed in the space of a short time. Therefore, the gap between the coverage on traditional media and that on entertaining media suggests some reflections that may be extended also beyond the Italian case. The increase of celebrity politics may have a different impact for men and women. For the former group, the visibility on gossip magazines can be regarded as complementary: a way for making their image more nuanced and interesting by allowing the politician to display openly his emotions and to reveal nice and sometimes moving details of his life. If voters look for different kinds of information, about political and institutional activities and policy stances, they can find it through other sources, since the male politician receives a regular and more traditional kind of coverage elsewhere, on a range of different media outlets.

For the latter group -women politicians- the visibility on gossip magazines can be even larger than that on quality press. Therefore, if the image of a female politician is crafted especially through the coverage of glossy and gossip magazines, it would be inevitably biased in terms of a disproportional attention given to trivial aspects. In contrast to what happens to men, the quality press is not able to compensate since it is affected by the trivialization effect as well: it happens, for instance, when the female politician became newsworthy also in the quality press as a consequence of a scoop appeared on a gossip magazine (i.e. when the pictures of a minister in bikini are spread by all the media). The consequence is that women politicians may became celebrity politicians as well as men, but their celebrity risks to be based on different roots. In conclusion, even if these new developments of political communication cannot be accused to be always sexist, since women politicians have become even more visible than men and apparently this may work to the their benefit, nevertheless we should be aware of the existence of a subtle discrimination.

\section{References}

- Calise, M. (2000). Il partito personale. RomaBari: Laterza.

- Campus, D. (2013). Women political leaders and the media. Houndmills: Palgrave McMillan.

- Carlin, D. B. \& K. L. Winfrey (2009). Have You Come a Long Way, Baby? Hillary Clinton, Sarah Palin, and Sexism in 2008 Campaign Coverage. Communication Studies 60 (4): 326-343.
- Cepernich, C. (2010). Campagna elettorale e campagna stampa intorno agli "inciampi" pubblici e privati di Silvio Berlusconi. Comunicazione Politica, XIII (1): 67-80.

- Ciaglia, A. \& Mazzoni, M. (2014). The politicization of entertainment media: A study of the Italian tabloid Chi during the 2013 electoral campaign, in Journalism, Online First, $10.1177 / 1464884914543169$. 
- Ciaglia A., Mazzoleni G., Mazzoni M. \& Splendore S. (2014). Politica e politici pop. Come i media di intrattenimento confezionano la comunicazione politica. Comunicazione Politica, XV (1): 79-96.

- Corner, J. \& Pels, D. (2003). Introduction In J. Corner \& D. Pels (eds.) Media and the Restyling of Politics. London: Sage.

- Dahlgren, P. (2009) Media and Political Engagement. Citizens, Communication, and Democracy, Cambridge: Cambridge University Press.

- David Marshall (1997). Celebrity and Power. Fame in Contemporary Culture. Minneapolis: University of Minnesota Press.

- Delli Carpini, M. X. \& Williams, B.A. (2001). Let Us Infotain: Politics in the New Media Environment. In W.L. Bennett \& R. Entman (eds.), Mediated Politics. Cambridge: Cambridge University Press.

- Falk, E. (2010). Women for President: Media Bias in Eight Campaigns. Urbana: University of Illinois Press.

- Freedman, J. (1997). Femmes Politiques: Mythes et Symboles. Paris : L'Harmattan.

- Giammaria, E. (2014). Primi ministri e governi nell'era della politica pop. Il caso italiano, Unpublished final dissertation, Two -year Master in Politics, Administation and Organization, University of Bologna.

- Global Media Monitoring Project (2010). Who makes the news?, www.whomakesthenews.org.

- Jamieson, K.H. (1988). Eloquence in an Electronic Age. The Transformation of Political Speechmaking. Oxford: Oxford University Press.

- Lakoff, R. (2003). Language, Gender, and Politics: Putting "Women" and "Power" in the Same Sentence in J. Holmes \& M. Meyerhoff (eds.) The Handbook of Language and Gender. Oxford: Blackwell.

- Langer, A. (2010). The politicization private persona: Exceptional Leaders or the New Rule? The Case of UK and the Blair Effect, The International Journal of Press/Politics, 15: 60-76.
- Mancini, P. (2011). Between Commodification and Lifestyle Politics. Does Silvio Berlusconi provide a New Model of Politics for the TwentyFirst Century? University of Oxford: Reuters Institute for the Study of Journalism.

- Mazzoleni, G. \& Shultz, W. (1999). Mediatization of Politics: A Challenge for Democracy?, Political Communication, 16: 247-261.

- Mazzoni, M. \& Ciaglia, A. (2014a). An incomplete transition? How Italian politicians manage the celebritisation of politics, Celebrity Studies, DOI:10.1080/19392397.2013.797656

- Mazzoni, M. and Ciaglia, A. (2014b). How Italian politics goes popular: Evidence from an empirical analysis of gossip magazines and TV shows, "International Journal of Cultural Studies", 14(4), pp. 381-398. DOI: $10.1177 / 1367877913496199$

- Riegert, K. (ed) (2007). Politicotainment. Television's Take on the Real. New York: Peter Lang.

- Roncarolo, F. (2004). Mediation of Italian Politics and the marketing of Leaders' Private Lives. Parliamentary Affairs, 57 (1): 108-117.

- Saraceno, C. (2013). The Womens' Protest: A Success with Many Shadows. In A. Bosco \& D. McDonnell (eds), From Berlusconi to Monti, Oxford: Berghahn.

- Schwartzenberg, R. (1977). L'état spectacle. Paris: Flammarion.

- Sreberny-Mohammadi, A. \& Ross, K. (1996). Women MPs and the media: Representing the Body Politics. Parliamentary Affairs. 49 (1): 103-15.

- Stanyer, J. (2007). Modern Political Communication, Cambridge: Polity Press.

- Stanyer, J. (2013). Intimate Politics, Cambridge, Polity Press.

- Stevens, A. (2007). Women, Power, and Politics (Houndmills: Palgrave).

- Street, J. (2003). The Celebrity Politician: Political Style and Popular Culture. In J. Corner \& D. Pels (eds.) Media and the Restyling of Politics. London: Sage. 
- Una storia italiana (2001). Milano: Mondadori.

- Van Zoonen, L. (2005). Entertaining the Citizen. When Politics and Popular Culture Converge, Oxford: Rowman \& Littlefield.

- Van Zoonen, L. (2006). The personal, the political and the popular. A woman's guide to celebrity politics. European Journal of Cultural Studies, 9 (3): 287-301.
- Ventura, S. (2012). Il racconto del capo. Berlusconi e Sarkozy. Roma-Bari: Laterza.

- Wheeler M. (2013). Celebrity Politics, Cambridge: Polity Press.

\section{Forma de Citación}

CAMPUS, Donatella and GIAMMARIA, Elena: Italian female ministers: A test for the celebrity politics? Revista Communication Papers, $N^{\circ}$, páginas 49 a 60. Departamento de Filología y Comunicación de la Universidad de Girona. Recuperado el _ de__ de 2 de: http://www.communicationpapers.es 